\title{
PENGARUH LATIHAN SMALL SIDED GAMES 4X4 DAN 8X8 TERHADAP PENINGKATAN KETERAMPILAN PASSING PADA PEMAIN SEPAKBOLA EKSTRAKURIKULER SMP NEGERI 2 GRATI KABUPATEN PASURUAN
}

\author{
Diki Satria Perdana \\ I Nengah Sudjana \\ Oni Bagus Januarto \\ Fakultas IImu Keolahragaan Universitas Negeri Malang \\ E-mail: dikisatria576@gmail.com
}

\begin{abstract}
Abstrak: In a game of football needed a good technical can do to the game of football which qualified .The purpose of this research is to know the influence of small sided exercise games $4 \times 4$ and $8 \times 8$ to increasing skill of passing on football player .Research method used is research experiment using design randomized control group pretestposttest design .The result of this research is there are a significant increase in test results of passing football before and after receiving training using methods small sided game $4 \times 4$ and $8 \times 8$.
\end{abstract}

Key words: Soccer, Small side games, passing

\begin{abstract}
Dalam permainan sepakbola dibutuhkan teknik yang baik untuk dapat melakukan permainan sepakbola yang berkualitas. Tujuan dari penelitian ini adalah untuk mengetahui pengaruh latihan small sided games $4 \times 4$ dan $8 \times 8$ terhadap peningkatan keterampilan passing pada pemain sepakbola. Metode penelitian yang digunakan adalah penelitian eksperimen menggunakan rancangan Randomized Control Group Pretest-Posttest Design. Hasil dari penelitian ini adalah terdapat peningkatan yang signifikan pada hasil tes passing sepakbola sebelum dan sesudah menerima latihan menggunakan metode small sided game 4x4 dan 8x8.
\end{abstract}

Kata kunci: sepakbola, small side games, passing.

Sepakbola merupakan salah satu cabang olahraga yang sangat populer di seluruh belahan dunia. Kepopuleran olahraga bisa dilihat dari begitu banyaknya masyarakat yang memainkannya. Permainan sepakbola pada tingkat profesional tidak sesederhana seperti yang biasa dimainkan ditingkat desa atau hanya untuk sekedar olahraga ringan yang biasa dilakukan untuk mengisi waktu luang. Dalam permainan sepakbola dibutuhkan teknik yang baik untuk dapat melakukan permainan sepakbola yang berkualitas.

Pada permainan sepakbola ada beberapa macam teknik dasar sepakbola yang perlu dikuasai, salah satunya adalah mengumpan atau mengoper bola (passing). Passing adalah seni memindahkan bola dari satu pemain ke pemain lain (Mielke, 2007: 19). Luxbacher (1998: 11) menyebutkan ada beberapa teknik dasar mengumpan bola, yaitu (1) inside of the foot, yaitu mengumpan bola dengan kaki bagian dalam, (2) operan outside of the foot, yaitu mengumpan bola dengan kaki bagian luar, dan (3) operan instep, yaitu mengumpan bola kura-kura kaki.

Permainan sepakbola pada tingkat profesional tidak sesederhana seperti yang biasa dimainkan ditingkat desa atau hanya untuk sekedar olahraga ringan yang biasa dilakukan untuk mengisi waktu luang. Dalam permainan sepakbola dibutuhkan teknik yang baik untuk dapat melakukan permainan sepakbola yang berkualitas. Tentunya untuk menjadi pemain profesional ada standar minimal yang harus dicapai yaitu melalui sebuah pelatihan. Sebuah prestasi tidak akan tercapai dengan sendirinya, namun melalui proses pelatihan dan pembinaan secara sistematis dan benar.

Pelatihan merupakan suatu proses untuk mencapai prestasi maksimal, tidak 
Diki Satria Perdana, Pengaruh Latihan Small Sided Games 4x4 Dan 8x8 Terhadap Peningkatan Keterampilan Passing Pada Pemain Sepakbola Ekstrakurikuler Smp Negeri 2 Grati Kabupaten Pasuruan

hanya mengandalkan bakat dan minat dari atlet tersebut, tetapi harus diikuti dengan pelatihan yang terprogram, berjenjang dan berkelanjutan untuk dapat menghadapi situasi pertandingan dan meningkatkan kemampuan atlet.

Latihan adalah "suatu proses yang sistematis dari berlatih atau bekerja, yang dilakukan secara berulang-ulang, dengan kian hari kian menambah jumlah beban pelatihan atau pekerjaanya" Harsono, (1988: 98 ). Dikatakan sistematis dalam pengertian, bahwa pelatihan dilaksanakan secara teratur, berencana, menurut jadwal, menurut pola dan sistem tertentu, metodis, ber-kesinambungan dari hal sederhana ke yang lebih kompleks. Berulang ulang berarti gerakan yang dipelajari harus diulangi sehingga pola gerakan yang sukar dapat dilakukan dengan mudah, otomatis dan reflektif pelaksanaannya.

Pelatihan hendaknya dapat merangsang sistem fisiologis tubuh, dimana rangsangan tersebut dapat dikatakan stress yang terus menerus di dalam tubuh, sehingga akan mengakibatkan adaptasi yang menghasilkan peningkatan kapasitas fungsional sistem tersebut (Brooks dalam Sajoto, 1988 : 115). Berdasarkan uraian pendapat para ahli di atas, dapat dijelaskan bahwa pelatihan adalah suatu proses berlatih atau aktivitas yang dilakukan secara sitematis, berulangulang dengan meningkatkan beban pelatihan secara progresif dan bersifat individual yang mengarah pada ciri-ciri fungsi fisiologis manusia untuk mencapai tujuan yang diinginkan.

Metode latihan SSG (small sided games) dirasa memenuhi tuntutan tersebut, adanya unsur keterampilan teknik dan kemampuan kondisi fisik memenuhi secara spesifik serta penggunaan waktu akan menjadi efektif. Prinsip spesifikasi akan memberikan man--faat yang maksimal manakala rang-sangan latihan mirip atau merupakan replikasi dari gerakan-gerakan yang dilakukan dalam olahraga sepakbola. Hoff, dkk, (2002) mengungkapkan bahwa kehadiran bola selama SSG memungkinkan peserta untuk meningkatkan kebugaran fisik serta kete-rampilan teknik dan taktik. Metode latihan SSG dirasa tepat bagi pemain usia muda, karena karakteristik latihan usia muda harus dimulai dari yang paling sederhana, mudah dilakukan, dan menyenangkan dengan unsur permainan. Lebih lanjut Scheunemann (2008:26) menegaskan bahwa " pada usia muda program latihan sebaiknya lebih terfokuskan kepada teknik bermain dan pembentukan karakter pemain tanpa melu-pakan faktor kesenangan dalam bermain atau fun aspect". Dengan tujuan menye-diakan wawasan baru dalam hal ini, dan mengacu pada beberapa pendapat para ahli, maka rancangan pelatihan small sided games dengan jumlah pemain $4 \times 4$ sebagai kelompok eksperimen I, dan jumlah pemain 8x8 sebagai kelompok eksperimen II. Dengan demikian, satu hal yang mendasar dalam penelitian ini adalah menerapkan jenis-jenis pelatihan yang spesifik pada olahraga sepakbola melalui metode pelatihan small sided games dengan ukuran lapangan yang berbeda.

Tujuan utama pelatihan adalah membantu atlet untuk meningkatkan keterampilan prestasinya semaksimal mungkin (Harsono, 1988:100). Ada empat aspek latihan yang perlu diperhatikan dan dilatih secara seksama oleh pelatih yaitu : a) latihan fisik, (b) latihan teknik, (c) latihan taktik, dan (d) latihan mental. Menurut Bompa (1999: 35) "pelatihan bertujuan untuk mencapai dan memperluas perkembangan fisik secara menyeluruh, menjamin dan memperbaiki perkembangan fisik khusus, memperbaiki dan menyempurnakan teknik, memperbaiki dan menyempurnakan strategi, memperbaiki kualitas, menjamin dan memelihara kondisi optimal, mempertahankan kesehatan, mencegah terjadinya cedera, memperkaya pengetahuan".

Tujuan pelatihan dapat didefinisikan dan dibagi dalam dua bagian, yaitu tujuan umum dan tujuan khusus, tujuan umum pelatihan adalah untuk menjuarai satu kompetisi sebagai sasaran terakhir berdasarkan kalender kompetisi yang ditetapkan. Sedangkan tujuan khusus pelatihan adalah untuk membentuk, meningkatkan dan mempertahankan kondisi biomotor, ability, fisiologis, psikologis dan keterampilan motorik dalam teknik dan taktik berdasarkan fase-fase yang ditetapkan, tentunya sesuai dengan prinsip-prinsip kepelatihan.

Latihan adalah suatu proses yang harus dilakukan secara sistematis dan berulangulang seperti yang dikemukakan oleh Harsono (1988:101) latihan adalah proses 
yang sistematis dari pada berlatih atau bekerja yang dilakukan secara berulang. Dalam latihan ada beberapa prinsip yang dianut agar latihan mendapatkan latihan yang optimal diantaranya: Latihan yang optimal harus menganut prinsip latihan beban lebih seperti yang diungkapkan oleh Harsono (2004: 9) bahwa beban latihan yang diberikan kepada atlet haruslah secara periodik dan progresif ditingkatkan. Kalau beban latihan yang diberikan tidak ditambah, maka berapapun lama dan berapa sering atlet latihan, prestasi atlet tidak mungkin meningkat. Prinsip latihan yang paling dasar adalah prinsip overload karena tanpa penerapan prinsip ini tidak mungkin atlet berprestasi. Atlet yang sudah merasa beban latihannya ringan harus ditingkatkan agar respon fisiologis dan psikologisnya meningkat. Menurut Sajoto (1988: 42) dengan latihan beban bertambah penyesuaian fisiologis dalam tubuh yang mendorong meningkatkan kekuatan otot. Pada usia dini latihan tidak dibatasi pada cabangan olahraga tertentu saja tetapi anak harus bebas melakukan berbagai cabang olahrga agar fisik berkembang secara maksimal. Menurut Harsono (2004: 11) anak tidak dianjurkan terlalu cepat dispesialisasikan pada satu cabang olahraga agar dia biasa mengembangkan dirinya secara multilateral (menyeluruh) baik dalam aspek fisik, mental maupun sosial. Latihan spesialisasi yaitu latihan yang mengarah kesatu tujuan yang khusus untuk meningkatkan kekuatan otot tertentu. Menurut O'Shea dalam Sajoto (1988: 42) menyatakan bahwa "Semua program khu-sus, sesuai dengan sasaran yang akan dicapai. Bila akan meningkatkan kekuatan, maka program latihan harus memenuhi syarat untuk tujuan meningkatkan kekuatan". Program latihan dalam beberapa hal hendaknya bersifat khusus. Namun perlu memperbaiki pula gerak yang dihasilkan, oleh karena itu latihan beban hendaknya dikaitkan dengan peningkatan keterampilan motorik khusus. Dengan kata lain latihan beban menuju pengingkatan kekuatan, hendaknya diprogram yang menuju ke nomor-nomor cabang olahraga yang bersangkutan. Menurut Harsono (1988:113) prinsip latihan individualisasi adalah latihan harus diren-canakan dan disesuaikan bagi setiap individu agar dengan demikian latihan tersebut dapat menghasilkan hasil yang terbaik (the best result) bagi individu tersebut. Setiap orang memiliki kelebihan dan kekurangan masingmasing begitu pula dengan setiap atlet mempunyai kelebihan dan kekurangan maka dalam memberikan program latihan tidak oleh disamaratakan harus memperhatikan kebutuhan atlet. Apabila dipaksakan dengan cara yang dikehendaki pelatih niscaya program latihan tidak akan menuai hasil yang optimal. Dalam latihan ada beberapa hal yang harus diperhatikan yaitu kemampuan atlet, ukuran atau intensitas latihan tidak boleh berlebihan atau kurang. Bila program latihan yang diberikan pada atlet berlebihan maka akan berdampak overtraining dan apabila yang diberikan terlalu ringan maka akan tidak memperoleh hasil sama sekali. Sesuai dengan pernyataan Harsono (2004: 12) bahwa atlet harus dilatih melalui suatu program yang intensif yang dilandaskan pada beban lebih secara progresif menambah beban kerja, pengulangan gerakan (repetisi) serta kadar intensitas dari repetisi tersebut. Dalam kualitas latihan ini bukan hanya latihan yang menggunakan waktu yang lama, pengeluaran keringat yang banyak, tetapi kualitas latihan ini adalah latihan yang diberikan dengan kebutuhan atlet, memberikan koreksi atau pengawasan yang begitu detail kepada atlet. Harsono (1988: 118) mengemukakan: Latihan yang bermutu adalah apabila latihan atau dril-dril yang diberikan memang benarbenar sesuai dengan kebutuhan atlet, apabila koreksi-koreksi yang konstruktif sering diberikan, apabila pengawasan dilakukan oleh pelatih sampai sedetail-detailnya gerakan, dan apabila prinsip-prinsip overload diterapkan baik dalam segi fisik maupun mental. Dari pernyataan di atas dapat ditarik kesimpulan bahwa latihan yang bermutu adalah latihan yang memperhatikan kebutuhan atlet dan koreksi yang konstruktif serta pengawasan yang sedatail-detailnya oleh seorang pelatih. Seorang yang ingin menuai hasil dari sebuah latihan bukanlah hal yang instan tetapi memerlukan waktu yang cukup lama dan pekerjaan yang banyak pula. Untuk menghindari atlet agar tidak mudah bosan atau menimbulkan kebosanan pada atlet maka pelatih harus memberikan program latihan bervariasi seperti yang 
Diki Satria Perdana, Pengaruh Latihan Small Sided Games 4x4 Dan 8x8 Terhadap Peningkatan Keterampilan Passing Pada Pemain Sepakbola Ekstrakurikuler Smp Negeri 2 Grati Kabupaten Pasuruan

dikemukakan oleh Harsono (1988: 121) untuk mencegah kemungkinan timbulnya kebosanan berlatih, pelatih harus kreatif dan pandai-pandai mencari dan menerapkan variasi-variasi dalam latihan.

Suatu faktor yang sangat penting dalam olahraga adalah faktor rileksasi karena dengan rileksasi mengurangi ketegangan otot-otot selama berlatih tidak mengalami istirahat yang cukup. Seperti yang diungkapkan Harsono (1988: 122) yaitu rileksasi adalah masalah yang sangat berhubungan dengan tinggi rendahnya ketengangan yang ada dalam otot-otot.

Banyak strategi yang bisa dikembangkan dalam permainan sepakbola, tetapi secara umum strategi dalam permainan sepakbola adalah bertahan dan menyerang. Tidak hanya berusaha mencetak gol sebanyak-banyaknya, namun juga berusaha menjaga gawang agar tidak kemasukan gol. Bertahan adalah suatu usaha untuk menggagalkan serangan lawan agar tidak bisa memasuki daerah pertahanan sendiri (Trisno, Online, 2013:1). Dalam melakukan strategi bertahan dibutuhkan konsentrasi dan tidak harus bergantung hanya pada pemain bertahan saja, tetapi semua pemain mempunyai kewajiban untuk bertahan, hanya saja setiap pemain mempunyai porsi yang berbedabeda dalam bertahan, tergantung posisi asli pemain.

Menyerang adalah suatu usaha membawa bola ke daerah pertahanan lawan untuk membuat gol (Trisno, Online, 2013:1). Untuk melakukan serangan, dibutuhkan kerjasama, konsentrasi dan kejelian membaca peluang. Secara umum ada dua faktor yang menjadi dasar jika ingin menjadi pemain sepakbola yaitu; (a). Fisik: fisik yang kuat adalah syarat dasar yang harus dimiliki seorang pemain sepakbola, karena dalam permainan sepakbola dituntut untuk berlari setiap saat untuk mengejar, menggiring, atau merebut bola dari lawan. (b). Teknik: teknik sangat penting dalam permainan sepakbola, karena dengan teknik akan lebih mudah dalam mengolah bola. Dari beberapa pendapat para ahli dapat disimpulkan bahwa taktik dalam sepakbola adalah suatu rangcangan dari menyerang ke bertahan dan sebaliknya hanya untuk memenangkan pertandingan.
Sekolah sepakbola (SSB) merupakan sebuah organisasi olahraga khususnya sepakbola yang memiliki fungsi mengembangkan potensi yang dimiliki atlet. Tujuan sekolah sepakbola (SSB) untuk menghasilkan atlet yang memiliki kemampuan yang baik, mampu bersaing dengan sekolah sepakbola (SSB) lainnya, dapat memuaskan masyarakat dan mempertahankan kelangsungan hidup suatu organisasi (Soedjono, 1992:2). Sekolah sepakbola (SSB) merupakan detak jantung pembinaan sepakbola usia muda di Indonesia. Latihan pada usia muda yang sistematis serta berkesinambungan merupakan harga mati dalam pembinaan menuju pesepakbola yang profesional dan handal. Tujuan utama sekolah sepakbola (SSB) sebenarnya untuk menampung dan memberikan kesempatan bagi siswanya dalam mengembangkan bakat yang dimilikinya.

Dalam kamus bahasa Inggris small adalah kecil, sided itu sisi atau bidang dan games adalah permainan. Sehingga bisa diartikan small sided games adalah permainan dalam bidang yang kecil. Bondarev (2011) mengungkapkan bahwa small sided games (SSG) adalah setiap permainan yang dimainkan dengan kurang dari sebelas anggota tim dan melakukannya di lapangan yang berukuran lebih kecil. Permainan small sided games memungkinkan pemain untuk mengalami situasi yang mereka hadapi selama memainkan pertandingan yang sebenarnya. Hal ini dikarenakan dalam permainan small sided games hampir mirip dengan pertandingan sebenarnya. Dalam small sided games pemain dapat meningkatkan kemampuan teknik, taktik dan aspek fisiologis pada permainan mereka (Owen, dkk, 2004). Lebih lanjut Hoff, dkk, (2002) menyatakan bahwa kehadiran bola selama small sided games memungkinkan peserta untuk meningkatkan kebugaran fisik serta keterampilan teknik dan taktik. Format yang dimaksud pada makalah ini adalah jumlah keseluruhan pemain dalam proses pelaksanaan small sided games. Sebagai contoh jika small sided games menggunakan format (4vs4), maka dalam pelaksanaannya empat pemain melawan empat pemain. Jadi total secara keseluruhan jumlah pemain adalah delapan pemain. Hal ini mengacu yang sebagaimana telah dijelaskan pada 
pembahasan di atas, dimana small sided games adalah permainan yang dimainkan kurang dari sebelas pemain dalam satu tim (11 vs 11), maka format dalam small sided games pun kurang dari sebelas pemain. Dalam latihan sepakbola modern dikenal dengan istilah small sided games, yang kirakira berarti permainan dengan lapangan yang diperkecil. Para pemain berlatih dalam lapangan yang kecil dengan sasaran dan tujuan yang spesifik, misalnya melatih passing, crossing, dribbling dan sebagainya. Dengan lapangan yang diperkecil, maka para pemain akan terbiasa untuk mengambil keputusan dengan cepat, sehingga ketika pertandingan mereka sudah tidak lagi merasa terkejut.

Permainan small sided games memungkinkan pemain untuk mengalami situasi yang mereka hadapi selama memainkan pertandingan yang sebenarnya dengan mengalami situasi ini selama latihan. Pemain dapat meningkatkan kemampuan teknis, taktis dan aspek fisiologis pada permainan mereka (Owen, dkk, 2004). Lebih lanjut Hoff, dkk, (2002) menyatakan bahwa kehadiran bola selama small sided games memungkinkan peserta untuk meningkatkan kebugaran fisik serta keterampilan teknik dan taktik.

Menurut Hariyono dan Yunus (1991:1) sepakbola bagi pemainnya merupakan suatu perjuangan yang melibatkan berbagai unsur antara lain kekuatan, keuletan, kecepatan, ketangkasan, daya tahan serta keberanian selama jangka waktu dua kali 45 menit. Sedangkan menurut Widodo (2002:1) sepakbola adalah olahraga permainan beregu yang dimainkan atas dasar penguasaan teknik dengan bola, kondisi fisik, semangat bertanding dan pengertian terhadap bentuk permainan itu sendiri. Berdasarkan pengertian di atas dapat disimpulkan bahwa sepakbola adalah sebuah permainan beregu yang sederhana ketika melakukan tetapi membutuhkan suatu perjuangan yang melibatkan berbagai unsur antara lain kekuatan, keuletan, kecepatan, ketangkasan, daya tahan serta keberanian selama jangka waktu dua kali 45 menit.

Sebelum bermain sepakbola, seseorang harus menguasai teknik dasar yang ada pada permainan sepakbola. Penguasaan teknik dasar merupakan keharusan untuk seseorang yang sungguh ingin menguasai keterampilan dalam bermain sepakbola. Hariyono dan Yunus (1991:18) menyatakan bahwa, "pada dasarnya teknik permainan sepakbola terdiri dari: teknik badan atau gerakan permainan sepakbola tanpa bola dan teknik dengan bola atau gerakan sepakbola dengan bola". Teknik badan adalah gerakan tanpa menggunakan bola yang ditujukan pada perkembangan kemampuan fisik untuk mencapai kesegaran fisik. Sedangkan teknik dengan bola yaitu gerakan-gerakan permainan sepakbola dengan menggunakan bola. Ushandoko (2002:34) membagi unsur-unsur teknik dengan bola terdiri dari: (a) menendang bola (shooting), (b) menerima bola (controlling), (c) mengumpan (passing), (d) menggiring bola (dribbling), (e) menyundul bola (heading), (f) melempar bola (throw in), (g) teknik penjaga gawang (goal keeper), (h) teknik gerak tipu (feinting) dan (i) perasaaan dengan bola (ball feeling). Passing adalah memindahkan bola dari satu pemain ke pemain lain. Luxbacher (2001:11) menyebutkan ada beberapa teknik dasar mengumpan bola, yaitu: (1) inside of the foot, yaitu mengumpan bola dengan kaki bagian dalam, (2) operan outside of the foot, yaitu mengumpan bola dengan kaki bagian luar dan (3) operan instep, yaitu mengumpan bola dengan menggunakan kura-kura kaki. Hariyono dan Yunus (1991:19) menyatakan bahwa passing menggunakan kaki bagian dalam banyak digunakan dalam permainan sepakbola. Dalam melakukan gerakan passing dengan kaki bagian dalam tingkat ketepatan umpan ke teman sangat besar, agar dapat mengirimkan bola dengan tepat kepada kawan perlu dilatih terus dan memperhatikan selalu kecermatan.

Kegiatan belajar mengajar yang terjadi saat ini tentu saja merupakan satu rangkaian kegiatan yang terjadi oleh interaksi antara guru dan peserta didik tentunya untuk mencapai tujuan pendidikan. Sebutan "peserta didik" itu menggantikan sebutan "siswa" atau "murid" atau "pelajar" atau "student" (Husdarta dan Nurlan Kusmaedi, 2010:3). Penyebutan peserta didik tentunya akan memberikan perlakuan secara menyeluruh dalam proses belajar mengajar dimana ada interaksi antar kedua pelaku pembelajaran. 
Diki Satria Perdana, Pengaruh Latihan Small Sided Games 4x4 Dan 8x8 Terhadap Peningkatan Keterampilan Passing Pada Pemain Sepakbola Ekstrakurikuler Smp Negeri 2 Grati Kabupaten Pasuruan

Seorang guru diharapkan menjadi jembatan antara tujuan pendidikan dengan peserta didik. Dalam penyelenggaraan program pendidikan jasmani hendaknya mencerminkan karakteristik program pendidikan jasmani itu sendiri yakni "developmently appropriate practice" (Samsudin, 2013:58). Dimana seorang pendidik memberikan tugas belajar sesuai dengan pertumbuhan dan perkembangan peserta didik, artinya tidak melampaui kemampuan siswa dalam pembelajaran gerak sehingga tercapailah tujuan pendidikan jasmani.

Untuk mencapai tujuan tersebut tentu saja seorang pendidik harus menguasai tentang bagaimana pertumbuhan dan perkembangan yang terjadi pada perserta didiknya, karena pada rentangan usia tertentu terdapat karakteristik yang berbeda. Karakteristik peserta didik sekolah menengah pertama berkisar antara 14-15 tahun. Perkembangan pada masa ini termasuk dalam masa adolesensi. Sugiyanto menyebutkan "Masa adolesensi merupakan masa transisi dari masa kanak-kanak menuju masa dewasa." (Sugiyanto, dkk 2007:176). Pada masa ini terjadi pertumbuhan yang sangat pesat meskipun pertumbuhan anak laki-laki lebih lambat dibandingkan dengan anak perempuan. Anak perempuan terjadi pada kisaran usia 8,5 hingga 11,5 tahun dengan puncak ratarata pada 12,5 tahun, sedangkan untuk anak laki-laki terjadi pada usia 10,5 hingga 14,5 dan mencapai puncak rata-rata pada 14,5 hingga 15,5 tahun.

Berdasarkan gambar tersebut terlihat bahwa terdapat perbedaan masa puber yang terjadi pada anak laki-laki dengan anak perempuan. Dimana masa kanak-kanak untuk perempuan hanya berlangsung hingga usia 11 tahun dan mengalami masa puber pada kisaran usia 11 hingga 15 tahun. Sedangkan anak laki-laki masa kanak-kanak terjadi hingga usia 12 tahun dan baru mengalami masa puber pada kisaran usia 12 hingga 16 tahun. Masa puber pada anak perempuan yakni terjadinya proses menstruasi pertama yang menunjukkan tandatanda seks sekunder seperti berkembangnya payudara, bertumbuhnya rambut kelamin dan sebagainya. Terdapat berbagai variasi menstruasi tentunya dipengaruhi pula seperti gizi makanan, kebudayaan atau ras. Sedangkan untuk anak lelaki masa puber biasanya terlihat dari pelebaran pangkal tenggorokan, adanya percepatan pertumbuhan scrotum dan testis.

Pada masa ini terdapat perbedaan secara morfologis yakni bertambah melebarnya bahu dibandingkan pinggulnya untuk anak lelaki sebaliknya pada anak perempuan terjadi pelebaran bagian pinggul diban-dingkan bahu dan pinggang. Pada masa adolesensi menuju dewasa terdapat pula perbedaan secara morfologis untuk anak laki-laki terjadi percepatan pertumbuhan pada tungkai sedangkan perempuan menga-lami perlambatan. Berikut ini merupakan hasil penelitian tentang perkembangan kemampuan fisik pada masa remaja (Husdarta dan Nurlan Kusmaedi, 2010:71). (1) Power otot yang merupakan kemampuan mengerahkan kekuatan dan kecepatan secara bersamasama mencapai tingkat optimal kurang lebih 1 tahun sesudah pencapain pertumbuhan ukuran tubuh maksimal. (2) Pada masa remaja pelak-sanaan program aerobik yang baik dapat meningkatkan kemampuan kardio-respiratori sampai sebesar $20 \%$.

Karena perbedaan fisik pada masa remaja ini sangat berdekatan antara usia SMP dan SMA maka Sumantri dan Syaodih (2007:46) membedakan profil perkembangan fisik antara siswa SLTP dengan SLTA.

Berdasarkan penjelasan tersebut maka dalam pengembangan model yang nantinya akan disampaikan, peneliti akan mempertimbangkan karakteristik-karekteristik pada siswa sekolah menengah pertama dimana siswa makin aktif dengan cabang olahraga yang dimainkan, perubahan pada fisik siswa maka mengharuskan guru untuk mengelompokkan siswa berdasarkan jenis kelamin. Hal ini dilakukan tentunya agar model yang akan disampaikan tepat guna untuk pembelajaran seusia mereka.

Dalam prinsip pendidikan tidak boleh hanya pada masa kanak-kanak saja tetapi juga harus dilakukan secara berkelanjutan. Begitu pula terhadap pembelajaran gerak berlangsung hingga sepanjang umur sebagai suatu bentuk proses pertumbuhan, perkembangan manusia baik secara fisik dan mental. Sedangkan dalam lingkungan sekolah pendidikan jasmani lebih dominan kepada pembelajaran moorik. Unsur-unsur pokok dalam pembelajaran motorik di 
sekolah menurut Decaprio adalah kekuatan, kecepatan, power, ketahanan, kelincahan, keseimbangan, fleksibilitas, dan koordinasi (Decaprio, 2013:41). Kekuatan merupakan unsur penting dalam pembelajaran motorik di sekolah. Hal ini tentunya berasal dari adanya stimulus terhadap gerak dan menimbulkan respon pada diri siswa. Rangkaian tersebut jika erjadi berulangulang maka akan menyebabkan pola gerak yang makin terkoordinasi dengan baik. Unsur dalam kekuatan itu sendiri akan membuat siswa makin tangkas dan bertenaga. Hal-hal yang mendukung munculnya kekuatan dalam diri siswa antara lain dengan kegiatan sederhana misalnya mengangkat dagu, mendorong, menarik, mengangkat benda atau senam pagi di sekolah. Pada pembelajaran motorik disekolah kecepatan bukan hanya di lihat dari kecepatan anak dalam berlari, tetapi bisa juga dinilai cepat dalam hal memvariasikan gerak yang satu dengan yang lain dengan baik, kecepatan tentunya dipengaruhi ooleh beberapa hal yakni seperti berat badan siswa, kekenyalan otot, faktor anatomi tubuh. Power merupakan suatu gabungan antara kekuatan dan kecepatan yakni dengan mongontraksikan otot secara maksimal. Biasanya gerakannya terjadi secara cepat dan singkat, biasanya berupa gerakan melompat, mengangkat beban atau melempar. Ketahanan merupakan salah satu unsur pokok dalam keterampilan motorik yakni merupakan hasil kapasistas psikologis siswa unuk menopang gerakan pada waku tertentu. Terkadang dihubungkan dalam ketahanan terhadap kekuatan atau dengan pernafasan. Ketahanan ditandai dengan kemampuan meneruskan gerakan ulang secara benar. Ketahanan dalam pembelajaran gerak dapat diukur dengan berbagai gerakan seperti mengangkat dagu, gerakan menahan bola, gerakan meng-angkat kaki dan sebagainya. Kelincahan merupakan kemampuan sese-orang untuk mengubah arah secara cepat dan tepat, yang dapat dilihat dari kemampuan siswa dalam bergerak cepat dari satu posisi ke posisi yang lain dari satu geerakan menuju gerakan lainnya. Keseimbangan merupakan hal penting dalam pembelajaran gerak. Keseimbangan itu sendiri merupakan kemampuan untuk menjaga sistem otot syaraf dalam kondisi diam untuk respon yang efisien demi mengendalikan tubuh saat bergerak secara efisien. Keseimbangan terbagi menjadi dua yakni keseimbangan dalam posisi diam dan keseimbangan dalam posisi bergerak. Seperti pada saat melakukan passing atas ketika bergerak maju atau mundur dengan cepat maka siswa harus mampu melakukan passing atas dengan keseimbangan yang bagus untuk menghasilkan passing atas yang baik. Salah satu unsur dalam pembelajaran gerak yakni fleksibilitas. Kemampuan gerakan badan yang dilakukan seseorang itulah fleksibilitas yang di dukung adanya keluasan pergerakan sendi pada tubuh manusia. Koordinasi merupakan hal penting dalam pelaksanaan pendidikan jasmani disekolah. Koordinasi merupakan kemampuan untuk menggabungkan berbagai jenis gerakan ke bentuk yang lebih khusus.

Berdasarkan unsur-unsur dalam pembelajaran gerak di atas, maka dari itu pada tahap masa remaja awal yang merupakan waktu yang tepat untuk meningkatkan kemampuan, menyempurnakan gerakan dan memperhalus keterampilan berbagai macam olahraga. Di dalam pendidikan jasmani pada masa ini merupakan tahapan penting bagi peserta didik untuk menyempurnakan keterampilan geraknya. Bagi mereka yang kurang memiliki keterampilan harus belajar menilai kemampuannya secara realistik dan menilai tujuan dari keterampilannya itu sendiri. Sehingga peserta didik bisa menilai kemampuannya sendiri dengan membandingkan dengan temannya yang mimiliki keterampilan yang lebih tinggi atau yang lebih rendah dari dirinya sendiri.

Pada masa ini ketertarikan dengan halhal baru dan hal-hal yang digemari sangat tinggi. Menurut Sugiyanto menyatakan "bentuk kegiatan yang digemari pada masa adolesensi ini seperti olahraga beregu, kegiatan yang menguji keterampilan tinggi, permainan perorangan maupun ganda dan pengembangan program latihan." (Sugiyanto, 2007:200). Bentuk kegiatan bolavoli itu sendiri merupakan permainan beregu sehingga diharapkan pada masa inilah siswa memperoleh pengetahuan pembelajaran yang lebih.

Pada kebutuhan anak remaja untuk melaksanakan gerak memerlukan adanya 
Diki Satria Perdana, Pengaruh Latihan Small Sided Games 4x4 Dan 8x8 Terhadap Peningkatan Keterampilan Passing Pada Pemain Sepakbola Ekstrakurikuler Smp Negeri 2 Grati Kabupaten Pasuruan

perhatian tersendiri. Seperti yang dijelaskan diatas bahwa pada masa ini anak saat melakukan bolavoli sudah mampu memperhalus gerakan, mampu untuk mengurutkan gerakan dengan mudah, sudah dapat memegang kendali, serta dapat merangkai beberapa gerakan menjadi satu gerakan yang berkelanjutan, meskipun begitu seorang guru harus tetap menyesuaikan proses belajar dan mengajar sesuai dengan siswa yang dihadapi.

Selain itu peningkatan keterampilan gerak sangat tepat terjadi pada masa ini, hal ini karena ketertarikan terhadap kegiatan yang baru sangat tinggi. Karakteristik siswa pada pendidikan sekolah menengah pertama menjunjung tinggi sportivitas dalam kegiatan pembelajaran pendidikan jasmani, sehingga diperlukan adanya kreativitas guru untuk menciptakan suatu pembelajaran yang dibutuhkan oleh peserta didik untuk mengikuti kegiatan pembelajaran Penjas. Salah satu materi dalam pembelajaran yakni disampaikan materi tentang bolavoli dimana dalam permainan bolavoli terdapat berbagai teknik dasar yang harus dimiliki oleh siswa, teknik dasar tersebut seperti servis, passing, smash, dan block. Keterampilan passing atas dalam bolavoli merupakan salah satu teknik yang memerlukan keterampilan yang baik.

Peningkatan keterampilan tentunya berasal dari penyampaian secara bertahap, ketika telah mencapai tahapan belajar maka diperlukan lagi peningkatan atau penghalusan gerak. Gerak dasar untuk melakukan passing atas yang benar adalah sebagai berikut:

- Sikap persiapan : Saat melakukan sikap persiapan yaang harus dilakukan adalah bergerak ke arah datangnya bola dimana posisi tepat berada dibawahnya, posisi bahu sejajar dengan sasaran, posisi kaki merenggang santai, bengkokkan sedikit lengan, kaki, dan pinggul. Setelah itu tahan posisi tangan 6 atau 8 inci di depan pelipis. Kemudian lihatah posisi bola dengan "jendela" yang dibentuk oleh tangan dan ikuti arah sasaran bola.

- Sikap pelaksanaan : Ketika bola sudah dalam jangkauan tangan diatas pelipis maka terimalah bola pada bagian belakang bawah, terimalah dengan dua persendian teratas dari jari dan ibu jari. Sedangkan untuk gerakan lengan dan kaki yakni dengan meluruskannya ke arah sasaran. Pindahkan berat badan ke arah sasaran, kemudian arahkan bola sesuai dengan ketinggian dan arah yang diinginkan.

- Gerak lanjutan : Setelah bola terlepas dari ujung jari maka luruskan tangan sepenuhnya, pinggul bergerak maju kearah sasaran, pindahkan berat badan ke arah sasaran. Peningkatan keterampilan siswa dengan menggunakan permainan diharapkan mampu mengatasi kebosanan dalam mengikuti kegiatan pembelajaran.

Ahmadi (1984:105) menyimpulkan "ekstrakurikuler adalah kegiatan-kegiatan di luar sekolah yang mempunyai fungsi pendidikan dan biasanya berupa klub-klub, misalnya olahraga, kesenian, ekspresi dan lain-lain". Jadi dari beberapa definisi program ekstrakurikuler dapat disimpulkan, bahwa program ekstrakurikuler adalah suatu program yang dilakukan di luar jam pelajaran, yang digunakan untuk menyelesaikan materi-materi pelajaran yang belum tersampaikan dengan tuntas pada kegiatan kurikuler. Contoh kegiatan ekstrakurikuler yang dilaksanakan di sekolah, dapat dilakukan pada kegiatan olahraga, seni, drama, pramuka, komputer dan lain-lain.

Menurut Sarifudin (1982:33) bahwa "program ekstrakurikuler dapat menunjang tercapainya tujuan pendidikan, dimana halhal yang tidak dapat terselesaikan dalam program yang telah ditentukan dalam jamjam pelajaran sekolah, dapat diberikan pada jam-jam di luar sekolah". Ahmadi (1984:105) menyimpulkan "ekstrakurikuler adalah kegiatan-kegiatan di luar sekolah yang mempunyai fungsi pendidikan dan biasanya berupa klub-klub, misalnya olahraga, kesenian, ekspresi dan lain-lain". Dari teori di atas mengenai tujuan ekstrakurikuler, dapat disimpulkan, bahwa ekstrakurikuler, memiliki beberapa tujuan misalnya: menunjang tujuan pendidikan, sebagi tempat mencari hiburan, sebagai tempat mengekspresikan diri, untuk membina siswa yang berminat pada satu atau beberapa cabang tertentu dan lain-lain. Menurut Koger (2005:19) passing berarti memindahkan bola dari kaki anda ke kaki pemain lain, dengan cara menendangnya. Passing bola dapat dilakukan dalam keadaan bola yang bervariasi baik diam, bergerak, melayang, atau melambung di udara.

Teknik passing di dalam permainan sepakbola adalah bahagian yang terpenting. 
Bila seorang pemain tidak mempunyai teknik passing yang baik, maka sulit bagi pemain tersebut untuk menjadi pemain top (ternama). Hampir setiap kesebelasan memperoleh kemenangan menciptakan gol dengan passing. Di samping itu teknik passing dalam upaya mengoper bola ke teman adalah hal yang dominan digunakan dalam rangka menguasai bola agar jangan direbut tim lawan. Menurut Djezed (1992:20) tujuan dari passing bola: (1) untuk memberikan bola kepada teman atau mengoper bola, (2) dalam usaha memasukkan bola ke gawang lawan, (3) untuk menghidupkan bola kembali setelah terjadi suatu pelanggaran seperti tendangan bebas, tendangan penjuru, tendangan hukuman, tendangan gawang dan sebagainya, (4) untuk melakukan pembersihan (clearing) dengan jalan menyapu bola yang berbahaya di daerah sendiri atau dalam usaha membendung serangan lawan pada daerah pertahanan sendiri.

Berdasarkan tujuan passing yang dikemukakan terdahulu, maka passing bola merupakan teknik dasar bermain sepakbola yang paling penting dan banyak digunakan dalam permainan sepakbola. Kesebelasan yang baik dan tangguh adalah suatu kesebelasan yang semua pemainnya menguasai teknik dasar passing bola dengan baik, dengan cepat, cermat dan tepat pada sasaran-sasaran pada teman maupun sasaran dalam membuat gol ke mulut gawang lawan (Sukatamsi, 1997:25). Passing bola dalam permainan sepakbola dapat dilakukan dengan: (1) kaki bagian dalam, (2) punggung kaki, (3) punggung kaki bagian dalam, (4) punggung kaki bagian luar. Sedangkan passing bola dengan (1) ujung kaki, (2) tumit kaki, (3) kaki bagian luar, (4) sol sepatu adalah cara passing yang jarang dilakukan saat bermain sepakbola (Witarsa, 1984:2). Passing dengan kaki bagian dalam pada teknik sepakbola biasanya digunakan saat mengoper bola pada teman dalam jarak pendek dan menengah bola-bola bawah. Pelaksanaannya adalah: (1) kaki tumpu ditempatkan di samping bola, (2) ujung kaku tumpu di arahkan ke lintasan jalan bola, (3) kaki tumpu ikut membantu gerakan kaki ayun atau kaki tendang, (4) lintasan kaki tendang diputar, kaki bagian dalam diarahkan ke arah lintasan jalan bola, lutut sedikit dibengkokkan, (5) telapak kaki tendang sejajar dengan tanah, (6) pukulan kaki bagian dalam pada bagian tengah bola (tepat tengah bola), (7) gerakan lanjutan dari kaki tending (Brown, 1992:215).

Berdasarkan latar belakang yang telah diuraikan dan pengumpulan referensi di atas maka peneliti akan melaksanakan penelitian dengan judul "Pengaruh Pelatihan Small Sided Games 4x4 dan 8x8 Terhadap Peningkatan Keterampilan Passing Pada Pemain Sepakbola Ekstrakurikuler SMP Negeri 2 Grati"

Tujuan penelitian adalah : (1) Untuk mengetahui pengaruh latihan small sided games dengan pemain $4 \times 4$ terhadap peningkatan keterampilan passing pada pemain sepakbola ekstrakurikuler SMP Negeri 2 Grati. (2) Untuk mengetahui pengaruh latihan small sided games dengan pemain 8x8 terhadap peningkatan keterampilan passing pada pemain sepakbola ekstrakurikuler SMP Negeri 2 Grati. (3) Untuk mengetahui perbedaan pengaruh antara masing-masing kelompok terhadap peningkatan keterampilan passing pada pemain sepakbola ekstrakurikuler SMP Negeri 2 Grati.

\section{METODE}

Metode penelitian ini adalah eksperimen. Eksperimen adalah suatu cara untuk meng-ungkapkan suatu hubungan antara dua variabel atau lebih dan juga untuk mencari pengaruh suatu variabel terhadap variabel lainnya. Berdasarkan metode eksperimen tersebut, maka digunakan rancangan Ran-domized Control Group Pretest-Posttest Design, Maksum (2009: 137). Rancangan ini mengungkapkan hubungan sebab akibat dengan cara melibatkan kedua kelompok, yang pemilihan kedua kelompok tersebut dilakukan dengan teknik acak. Variabel-variabel yang diteliti meliputi (a) variabel bebas berupa kombinasi latihan power tungkai dan latihan komando (b) variabel terikat yaitu keterampilan passing sepakbola. Rancangan penelitian di atas dapat dijelas-kan sebagai berikut : (1) Subjek penelitian diambil secara acak melalui random menjadi 2 kelompok. (2) Masing-masing kelompok dilakukan pretest, kelompok eksperimen small sided games $4 \times 4$ diberi simbol (TO1), kelompok eksperimen small sided games 8x8 diberi 
Diki Satria Perdana, Pengaruh Latihan Small Sided Games 4x4 Dan 8x8 Terhadap Peningkatan Keterampilan Passing Pada Pemain Sepakbola Ekstrakurikuler Smp Negeri 2 Grati Kabupaten Pasuruan

simbol (TO2). (3) Kelompok eksperimen 1 diberi perlakuan yaitu pela-tihan small sided games 4x4 dengan simbol (X1) dan kelompok eksperimen 2 diberi perlakuan yaitu pelatihan small sided games $8 \times 8$ dengan simbol (X2) (4) Setelah delapan minggu pelatihan selanjutnya dilakukan posttest kepada ke dua kelompok. Kelompok eksperimen small sided games $4 \times 4$ diberi simbol (T1), kelompok eksperimen small sided games $8 \times 8$ diberi simbol (T2)

Lamanya pelatihan 6 minggu diharapkan akan memberikan efek yang berarti bagi subjek penelitian, sehingga apabila frekuensi pelatihan dilakukan 3 kali per minggu, maka program pelatihan dilakukan sebanyak 18 kali pelatihan (Pate, 1991:95). Perlakuan dalam penelitian ini berlangsung selama 18 kali pertemuan, dengan rincian pelatihan tiap minggu dilakukan sebanyak 3 kali mengacu pada pendapat di atas tentang frekuensi pelatihan yang dilakukan 3 kali perminggu. Populasi dalam penelitian ini adalah ber-jumlah dua puluh empat orang yang meng-ikuti kegiatan ekstrakurikuler sepakbola pada sekolah SMP Negeri 2 Grati Kabupaten Pasuruan. Populasi di atas akan dijadikan anggota sampel secara keseluruhan, de-ngan kata lain penelitian ini merupakan penelitian populasi. Proses pembagian ang-gota populasi ke dalam kelompok dilakukan secara random. Randomisasi untuk mendapatkan kedua kelompok tersebut dengan maksud memberikan kesempatan kepada semua objek populasi untuk memperoleh kesempatan yang sama. Hasil randomisasi dapat memudahkan untuk menentukan kelompok eksperimen I dan eksperimen II.

Variabel adalah suatu konsep yang memiliki variabilitas atau keragaman yang menjadi fokus penelitian (Maksum, 2009: 29). Variabel dalam penelitian ini terdiri atas variabel bebas (independent variable) dan variabel terikat (dependent variable). Variabel-variabel ini dapat dijelaskan sebagai berikut: Variabel-variabel dalam penelitian ini terdiri atas: (a) Variabel bebas dalam penelitian ini adalah program pelatihan small sided game $4 \times 4$ dan pelatihan small sided games $8 \times 8$. (b) Variabel terikat dalam penelitian ini adalah keterampilan passing pada pemain sepakbola. Dalam penelitian ini dibagi menjadi beberapa tahap dalam pelaksanaannya sebagai berikut:
Tahap Persiapan (a) Studi kepustakaan. (b) Menentukan populasi dan sampel. (c) Mengurus surat ijin penelitian. (d) Menghubungi subjek penelitian yang berperan sebagai sampel. (e) Membagi 2 kelompok sesuai dengan rancangan penelitian. (f) Menyiapkan sarana dan prasarana yang diperlukan dalam melaksanakan tes seperti stopwatch, peluit, bendera, meteran, dan pencatat hasil. (g) Melaksanakan pretest passing sepakbola pada tanggal 23 Mei 2015. (h) Pelaksanaan program pelatihan dimulai pada tanggal 25 Mei 2015 sampai 3 Juli 2015 (i) Tes akhir (post-test) passing sepakbola setelah diberikan pelatihan selama 6 minggu pada tanggal 4 Juli 2015. Pelaksanaan latihan diberikan pada hari Senin, Rabu, dan Jum'at bertempat di lapangan Patal Grati Kabupaten Pasuruan. Pemberian pelatihan sesuai dengan program latihan yang telah ada. Pelatihan dibagi menjadi tiga bagian yaitu: pemanasan (warming up), inti, dan pendinginan (cooling down).

Pemanasan diperlukan untuk tujuan latihan yang baik sebelum masuk latihan inti dari sebuah kepelatihan setelah itu diteruskan dengan pendinginan. Pemanasan dikerjakan secara khusus yaitu melakukan kegiatan peregangan untuk anggota gerak atas dan bawah serta melakukan peregangan untuk otot perut, lengan, bahu dan tungkai maka, dilakukannya pemanasan menggunakan permainan dengan durasi 15 menit.

Pendinginan dilakukan setelah latihan inti diberikan tujuannya untuk mempercepat turunnya temperatur otot keposisi awal sebelum pemanasan dalam waktu 10 menit. Pengumpulan data merupakan bagian terpenting untuk mengetahui kemampuan atau hasil dari pelatihan. Pengumpulan data dilakukan dengan tes passing sepakbola dilakukan sebelum pelatihan atau pretest dan sesudah pelatihan atau posttest. Pengambilan data berdasarkan banyaknya passing sepakbola yang didapat. Instrumen yang digunakan dalam penelitian ini adalah tes keterampilan passing sepakbola. Pengukuran kemampuan menggiring bola dengan tes keterampilan passing yang diadopsi dari Winarno (2006: 49). (1) Tujuan: untuk menilai kemampuan menyepak dan menghentikan bola. (2) Alat/fasilitas: bola 1 buah, stopwatch 1 buah, alat tulis, kapur dan formulir. (3) Dinding pantul (tembok atau 
papan). (4) Pelaksanaan: Peserta berdiri dibelakang garis batas, bola diletakkan di depan kakinya dalam keadaan siap menyepak bola. (5) Setelah peserta siap, maka pengambil waktu memberi aba-aba MULAI dan menjalankan stopwacthnya. Peserta segera menyepak bola ke dinding pantul. Pantulan bola kembali dihentikan dan ditahan sebentar dan segera disepak kembali ke arah dinding. Tes ini dilakukan selama 10 detik. (6) Hasil skor peserta adalah keseluruhan hasil menyepak dan menghentikan bola yang dilakukan secara sah dari belakang selama 10 detik.

Untuk menguji hipotesis penelitian, digunakan teknik statistik uji-t karena hanya ada dua variabel. Uji-t adalah teknik statistik yang digunakan untuk menguji signifikansi perbedaan dua buah mean yang berasal dari dua buah distribusi. Sebelum data dianalisis, terlebih dahulu dilakukan uji prasyarat yaitu uji normalitas dan uji homogenitas. Untuk mengetahui apakah data berdistribusi normal dan homogen, maka dilakukan uji normalitas, untuk melakukan uji-t tersebut akan digunakan program SPSS 17.0.

\section{HASIL}

Deskriptif Statistik Kelompok Small Sided Game 4 x 4. Deskripsi data yang akan disajikan berupa data hasil penelitian tes keterampilan passing sepakbola yang dilakukan oleh kelompok latihan passing menggunakan small sided game $4 \times 4$.

Tabel 1. Deskripsi data kelompok Small Sided Game 4x4

\begin{tabular}{lcc}
\hline \multicolumn{1}{c}{ Deskripsi } & Pre-test & Post-test \\
\hline Rata-rata & 3,620 & 7,7500 \\
\hline
\end{tabular}

\begin{tabular}{cc}
\hline Deskripsi & Pre-test Post-test \\
\hline Peningkatan & 114,088 \\
\hline
\end{tabular}

Dari Tabel 1 di atas diketahui bahwa nilai rata-rata (mean) kelompok latihan passing sepakbola menggunakan metode Small Sided Game 4x4 pada pre-test lebih kecil dari pada post-test mempunyai perbedaan yang relatif kecil, yaitu 3,620 dengan 7,7500 dan peningkatannya sebesar 114,088 . Selanjutnya akan dijelaskan data hasil penelitian tes keterampilan passing sepak-bola yang dilakukan oleh kelompok Small Sided Game 8x8 yang meliputi mean (rata-rata).

Tabel 2. Deskripsi data kelompok metode Small Sided Game 8x8.

\begin{tabular}{lcc}
\hline \multicolumn{1}{c}{ Deskripsi } & Pre-test & Post-test \\
\hline Rata-rata & 4,6250 & 5,8125 \\
\hline Peningkatan & 25,675 \\
\hline
\end{tabular}

Dari Tabel 2 di atas, diketahui bahwa nilai rata-rata (mean) kelompok latihan passing sepakbola menggunakan metode Small Sided Game 8x8 pada pre-test lebih kecil dari pada post-test mempunyai perbedaan yang relatif kecil, yaitu 4,6250 dengan 5,8125 dan peningkatannya sebesar 25,675.

Hasil latihan keterampilan passing sepak-bola yang menggunakan metode small sided game $4 \times 4$ dan $8 \times 8$. Data pre-test dilakukan sebelum perlakuan dan data posttest dilaku-kan sesudah adanya perlakuan yang berupa pelatihan menggunakan metode small sided game $4 \times 4$ dan small sided game $8 \times 8$. Analisis data dilakukan dengan meng-gunakan metode Paired Sample T-Test. Hasil dari analisis tersebut adalah sebagai berikut:

Tabel 3. Hasil Uji beda Pretest dan Posttest

\begin{tabular}{|c|c|c|c|c|c|c|c|c|c|}
\hline \multicolumn{10}{|c|}{ Paired Differences } \\
\hline & & Mean & $\begin{array}{l}\text { Std. } \\
\text { Dev }\end{array}$ & $\begin{array}{l}\text { Std. } \\
\text { Error } \\
\text { Mean }\end{array}$ & $\begin{array}{l}95 \% \\
\text { Confidence } \\
\text { Interval of } \\
\text { the } \\
\text { Difference }\end{array}$ & & $t$ & $d f$ & $\begin{array}{c}\text { Sig. } \\
(2- \\
\text { tailed) }\end{array}$ \\
\hline & & & & & Lower & Upper & & & \\
\hline Pair & $\begin{array}{l}\text { PreSSG4x4 - } \\
\text { PostSSG4x4 }\end{array}$ & -4.12500 & .64087 & .22658 & -4.66078 & -3.5892 & -18.205 & 7 & .000 \\
\hline $\begin{array}{l}\text { Pair } \\
1\end{array}$ & $\begin{array}{l}\text { PreSSG8x8 - } \\
\text { PostSSG8x8 }\end{array}$ & -1.18750 & 1.16726 & .29182 & -1.80949 & -.56551 & -4.069 & $\begin{array}{l}1 \\
5\end{array}$ & .001 \\
\hline
\end{tabular}


Diki Satria Perdana, Pengaruh Latihan Small Sided Games 4x4 Dan 8x8 Terhadap Peningkatan Keterampilan Passing Pada Pemain Sepakbola Ekstrakurikuler Smp Negeri 2 Grati Kabupaten Pasuruan

Berdasarkan table 3 di atas didapatkan hasil sebagai berikut: Pelatihan passing sepakbola dengan menggunakan metode small sided game $4 \times 4$ : Merumuskan hipotesis statistik: $H_{0}: \mu_{2}=\mu_{1}$ tidak ada peningkatan yang signifikan pada hasil tes passing sepakbola sebelum dan sesudah menerima pelatihan menggunakan metode small sided game $4 \times 4 . \quad H_{1}: \mu_{2}>\mu_{1}$ ada peningkatan yang signifikan pada hasil tes passing sepakbola sebelum dan sesudah menerima pelatihan menggunakan metode small sided game $4 \times 4$. $\alpha=0,05$, Nilai Sig. (2tailed) $=0,000, H_{0}$ diterima jika $\alpha \leq$ Sig. (2tailed), keputusan: karena nilai $\alpha(0,05)>$ Sig. (2-tailed) $(0,000)$ maka $H_{0}$ ditolak, bahwa ada peningkatan yang signifikan pada hasil tes passing sepakbola sebelum dan sesudah menerima metode latihan small sided game $4 \times 4$. Pelatihan passing sepakbola dengan metode small sided game 8x8: Merumuskan hipotesis statistic $H_{0}: \mu_{2}=\mu_{1}$ tidak ada pe- ningkatan yang signifikan pada hasil tes passing sepakbola sebelum dan sesudah menerima pelatihan meng-gunakan metode small sided game $8 \times 8 . H_{1}: \mu_{2}>\mu_{1}$ ada peningkatan yang signifikan pada hasil tes passing sepakbola sebelum dan sesudah menerima pelatihan menggunakan metode small sided game $8 \times 8 . \alpha=0,05$, Nilai Sig. (2-tailed) $=0,001, H_{0}$ diterima jika $\alpha \leq$ Sig. (2-tailed), uji pihak kanan., Keputusan: karena nilai $\alpha(0,05)>$ Sig. (2-tailed) $(0,001)$ maka $H_{0}$ ditolak, bahwa ada peningkatan yang signifikan pada hasil tes passing sepakbola sebelum dan sesudah menerima metode latihan small sided game $8 \times 8$.

Pengujian beda rata-rata antar kelompok dua sample (independent sample T-test) dilakukan untuk mengetahui perbedaan rata-rata antar kelompok. Nilai yang digunakan dalam penghitungan uji independent sample T-test.

Tabel 4. Keputusan Hasil Uji Beda (Paired Sample T-test)

\begin{tabular}{|c|c|c|c|c|c|c|c|c|c|}
\hline \multicolumn{10}{|c|}{ Paired Differences } \\
\hline & & Mean & $\begin{array}{l}\text { Std. } \\
\text { Dev }\end{array}$ & $\begin{array}{l}\text { Std. } \\
\text { Error } \\
\text { Mean }\end{array}$ & $\begin{array}{l}95 \% \\
\text { Confidence } \\
\text { Interval of } \\
\text { the } \\
\text { Difference }\end{array}$ & & $t$ & $d f$ & $\begin{array}{c}\text { Sig. } \\
(2- \\
\text { tailed })\end{array}$ \\
\hline & & & & & Lower & Upper & & & \\
\hline Pair 1 & 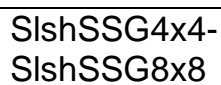 & 3.1250 & 1.12599 & .39810 & 2.18365 & 4.06635 & 7.850 & 7 & .000 \\
\hline
\end{tabular}

Uji beda rata-rata hasil latihan passing sepakbola Merumuskan hipotesis statistik: $H_{0}: \mu_{2}=\mu_{1}$ tidak terdapat perbedaan yang signifikan antara rata-rata hasil latihan keterampilan passing sepakbola yang diberi metode pelatihan menggunakan small sided game $4 \times 4$ dan metode $8 \times 8$. $H_{1}: \mu_{2} \neq \mu_{1}$ Terdapat perbedaan yang signifikan antara ratarata hasil latihan keterampilan passing sepakbola yang diberi metode pelatihan menggunakan small sided game $4 \times 4$ dan metode 8x8. $\alpha=0,05$, Nilai Sig. (2-tailed) $=$ $0,000, H_{0}$ diterima jika $\alpha \leq$ Sig. (2-tailed), Keputusan: karena nilai $\alpha(0,05)>$ Sig. (2tailed) $(0,000)$ maka $H_{0}$ ditolak, bahwa, terdapat perbedaan yang signifikan antara rata-rata hasil latihan keterampilan passing sepakbola yang diberi metode latihan menggunakan small sided game $4 \times 4$ dan metode latihan menggunakan small sided game $8 \times 8$. Untuk mengetahui metode mana yang mengalami peningkatan lebih tinggi terhadap hasil latihan passing cukup hanya dengan melihat selisih nilai mean yang paling besar, dari tabel $1.5 \mathrm{di}$ atas pelatihan passing menggunakan metode small sided game $4 \times 4$ memiliki selisih nilai mean yang lebih tinggi yaitu 4,125 di bandingkan dengan metode small sided game $8 \times 81,875$, artinya pelatihan menggunakan metode small sided game 4x4 memberikan peningkatan hasil latihan passing sepakbola yang lebih tinggi dibandingkan dengan metode small sided game $8 \times 8$. Dari hasil tersebut didapatkan kesimpulan terkait hipotesis awal sebagai berikut: 
Tabel 5. Keputusan Hasil Uji Beda (Paired Sample T-test)

\begin{tabular}{llll}
\hline $\begin{array}{l}\text { Kelompok } \\
\text { Yang Diuji }\end{array}$ & $\begin{array}{l}\text { Nilai } \\
\text { Signf }\end{array}$ & $\begin{array}{l}\text { Taraf } \\
\text { Signf } \\
(\boldsymbol{\alpha})\end{array}$ & keputusan \\
\hline $\begin{array}{l}\text { Passing } \\
\text { sepakbola } \\
\text { metode }\end{array}$ & 0,000 & 0,05 & $H_{0}$ ditolak \\
$\begin{array}{l}\text { SSG } 4 \times 4 \\
\text { Passing }\end{array}$ & 0,001 & 0,05 & $H_{0}$ ditolak \\
$\begin{array}{l}\text { sepakbola } \\
\text { metode }\end{array}$ & & & \\
SSG 8x8 & & & \\
\hline
\end{tabular}

Berdasarkan tabel 4 di atas dapat dideskripsikan untuk menjawab rumusan masalah penelitian yang diajukan oleh peneliti. Kesimpulannya adalah sebagai berikut: (1) Diketahui bahwa ada peningkatan yang signifikan pada hasil tes passing sepakbola sebelum dan sesudah menerima pelatihan menggunakan metode small sided game $4 \times 4$. (2) Sedangkan untuk kelompok passing sepakbola yang menggunakan metode small sided game $8 \times 8$, juga ada peningkatan yang signifikan pada hasil tes passing sepakbola sebelum dan sesudah menerima pelatihan tersebut.

\section{PEMBAHASAN}

Kombinasi latihan small sided game $4 \times 4$ dan $8 \times 8$ yang dilakukan selama 18 kali pertemuan (tiga kali dalam satu minggu) berpengaruh terhadap prestasi peningkatan keterampilan passing peserta ekstrakurikuler sepakbola SMPN 2 Grati Kabupaten Pasuruan dalam melakukan keterampilan passing ke dinding atau papan. Hal ini berdasarkan hasil analisis varian satu jalur tes awal dan tes akhir keterampilan passing yang dilakukan pada kelompok small sided game $4 \times 4$ dan $8 \times 8$, dengan hipotesis nihil ditolak. Berdasarkan analisis tersebut dapat disimpulkan bahwa ada pengaruh yang signifikan dengan latihan small sided game 4x4 dan 8x8 terhadap keterampilan passing sepakbola. Dengan melakukan latihan yang sistematis, terstruktur, berulang-ulang, dan jumlah beban latihan kian hari kian meningkat, akan mampu menghasilkan tujuan dari latihan yang dilakukan. Tidak hanya itu, dalam latihan juga memerlukan beberapa aspek-aspek yang perlu diperhatikan. Harsono (1988:100) menyatakan bahwa "beberapa komponen fisik yang perlu diperhatikan untuk dikembangkan adalah daya tahan kardiovaskuler, daya tahan kekuatan (strength), kelentukan (flexibility), kecepatan (speed), stamina, kelincahan (agility) dan power". Selain itu penelitan Cahyono (2014) dengan judul Pengaruh Latihan Single Leg Barriers Hops terhadap Peningkata Prestasi Long Pass pada Sekolah Sepakbola Malang Post Usia 13-15 Tahun, bahwa kedua bentuk latihan ini dapat digunakan untuk meningkatkan prestasi tendangan long pass dan memberikan pengaruh yang lebih baik dibandingkan dengan kelompok kontrol dengan latihan komando. Sehingga dapat disimpulkan dari beberapa hasil penelitian tersebut, bahwa latihan power tungkai terbukti dapat meningkatkan keterampilan pada shooting dan long pass pada passing.

Berdasarkan sesuai dengan perolehan skor tes keterampilan passing kelompok komando dapat disimpulkan bahwa latihan ini tidak ada pengaruh terhadap prestasi passing. Berdasarkan hasil uji hipotesis analisis varians yang dilakukan dengan menggunakan uji $\mathrm{F}$ skor keterampilan skor awal dengan skor akhir pada kelompok latihan Komando diperoleh hasil uji signifikasi yaitu, $F_{\text {hitung }}<F_{\text {tabel}}$, maka dari itu dapat disimpulkan bahwa tidak ada perbedaan yang signifikan antara hasil keterampilan skor awal dengan skor akhir kelompok latihan komando. Ditunjukkan dari penurunan rata-rata skor awal dan rata-rata skor akhir, hal itu berarti menunjukkan tidak adanya pengaruh yang signifikan. Dalam penelitian ini, latihan komando merupakan salah satu bentuk latihan untuk meningkatkan keterampilan dan kemampuan fisik pemain yang diberikan sesuai instruksi pelatih, namun dalam latihan ini tidak memberikan pengaruh yang signifikan terhadap peningkatan keterampilan passing.

Harsono (1988:101) yang menyatakan bahwa latihan adalah "proses yang sistematis dari berlatih atau bekerja, yang dilakukan secara berulang-ulang, dengan kian hari kian menambah jumlah beban latihan atau pekerjaan". Berdasarkan dari hasil penelitian Cahyono (2014: i) dengan judul Pengaruh Latihan Single Leg Barriers 
Diki Satria Perdana, Pengaruh Latihan Small Sided Games 4x4 Dan 8x8 Terhadap Peningkatan Keterampilan Passing Pada Pemain Sepakbola Ekstrakurikuler Smp Negeri 2 Grati Kabupaten Pasuruan

Hop terhadap Peningkatan Prestasi Long Pass pada Sekolah Sepakbola Malang Post Usia 13-15 Tahun, disimpulkan bahwa tidak ada pengaruh pada latihan komando.

Dari penelitian yang telah dilakukan beberapa hal yang harus diperhatikan adalah tujuan dari penelitian telah tercapai yaitu mengetahui pengaruh latihan small sided games dengan pemain $4 \times 4$ dan $8 \times 8$ terhadap peningkatan keterampilan passing pada pemain sepakbola. Pencapaian tujuan dari penelitian dapat terpenuhi karena didukung oleh adanya saran dan masukan selama melakukan kegiatan penelitian. Penggunaan model penelitian eksperimen ini untuk memecahkan masalah penelitian juga dipertimbangkan melalui teori-teori ahli yang mendukung selama proses penelitian. Berdasarkan hasil penelitian ini menunjukkan bahwa palatihan small sided games, juga dapat meningkatkan keteram-pilan passing. Hasil ini relevan dengan beberapa hasil penelitian yang dilakukan oleh penelitipeneliti sebelumnya, seperti Owen, dkk, (2004), yang dalam penelitiannya mengungkap bahwa pelatihan small sided games dapat meningkatkan beberapa aspek salah satunya keterampilan teknik. Demikian pula Hoff, dkk, (2002) dimana dalam penelitiannya telah membuktikan salah satu dampak pelatihan small sided games, yakni dapat meningkatkan keterampilan teknik.

Selain mengkonfirmasi laporan yang ada peningkatan keterampilan passing, pada small sided games $4 \times 4$ lebih optimal dari pada kelompok $8 \times 8$. Adanya perbedaan tersebut karena, ruang yang sangat luas dan frekuensinya yang sangat tinggi, maka gerak pemain pada kelompok eksperimen I atau small sided games $4 \times 4$ lebih luas dari kelompok eksperomen II atau small sided games $8 \times 8$. Sehingga teknik dalam kelompok eksperimen I lebih sering dilakukan, tidak terkecuali keterampilan teknik passing.

\section{KESIMPULAN}

Terjadi peningkatan yang signifikan akibat penerapan model pelatihan menggunakan metode small sided game terhadap hasil latihan keterampilan sepakbola. Meskipun terdapat perbedaan yang signifikan antara penerapan model latihan SSG $4 \times 4$ dan SSG $8 \times 8$ tetapi hasilnya sama, yaitu dapat meningkatkan latihan keterampilan passing sepakbola. Serta latihan menggunakan metode small sided game $4 \times 4$ akan memberikan peningkatan hasil latihan yang lebih tinggi dibandingkan dengan metode latihan small sided game 8x8.

\section{SARAN}

Hasil penelitian ini dapat dijadikan kajian dan masukan bagi pelatih ekstrakurikuler ataupun pelatih SSB bahwa, dengan penggunaan metode small sided game $4 \times 4$ dalam latihan sepakbola khususnya passing, lebih efektif dan efisien dibandingkan dengan metode small sided game 8x8. Perlu dilakukan penelitian lanjut terkait dengan pengaruh penggunaan metode small sided game dalam pelatihan sepakbola atau cabang olahraga yang lain.

\section{DAFTAR PUSTAKA}

Abdoellah, A. 1981. Olahraga Untuk Perguruan Tinggi. Yogyakarta: Sastra hudaya.

Ahmadi, Nuril. 2007. Permainan Bolabasket. Surakarta: Era Intermedia.

Bompa, T. O. 1999. Periodezation Theory and Methodology of Training. Illions : Kendal Hunt Pubhlishing Company

Bondarev, D.V. (2011). Factors influencing cardiovascular responses during small-sided soccer games performed with recreational purposes. Journal Sevastopol National Technical University

Brown, Eugene W. Youth Soccer A Complete Handbook, (USA, Cooper Publishing Group LLC, 1992.

Cahyono, Dwi Endra. 2014. Pengaruh Latihan Single Leg Barriers Hop terhadap Peningkatan Prestasi Long Pass Pada Sekolah Sepakbola Malang Post Usia 13-15 Tahun. Skripsi tidak diterbitkan. Malang: UM 
Decaprio, Richard. Aplikasi Teori

Pembelajaran Motorik Di Sekolah. Jogjakarta: Diva Press, 2013.

Harsono. 1988. Coaching dan Aspek-Aspek Psikologis dalam Coaching. Jakarta: P2LPTK, Depdikbud.

Harsono. 2004. Perencanaan Program Latihan. Bandung

Hoff J, Wisløff U, Engen LC. (2002) Soccer specific aerobic endurance training. British Journal Sports Medicine ;36:218-21.

Husdarta dan Nurlan Kusmaedi. Pertumbuhan dan Perkembangan (Olahraga dan Kesehatan). Bandung: Alfabeta, 2010.

Jones, S., \&Drust, B. (2007). Physiological and technical demands of $4 v 4$ and 8 $\checkmark 8$ in elite youth soccer players. Kinesiology, 39, 150-156.

Luxbacher, J.A. 1998. Sepakbola. Jakarta: PT. Grafindo. Malang (UM Press).

Maksum, A. (2009), Metodologi Penelitian Dalam Olahraga. UNESA.

Muhdhor, Zidane. 2013. Menjadi Pemain Sepakbola Profesional. Kata Pena.

Owen, A., Twist C dan Ford, P. (2004). Small-Sided Games: The Physiological And Technical Effect Of Altering Pitch Size And Player Number. Journal Insight-Issue 2, Volume 7

Pate RR. Mc., Clengham B., Rotella R., (1993). Dasar-Dasar Ilmiah Kepelatihan, (Scientific Foundation of Coaching), Terjemahan Kasiyo Dwijowinoto), Semarang: IKIP Semarang Press.

Sajoto, M. 1988. Pembinaan Kondisi Fisik dan Olahraga. Jakarta. Depdikbud Dirjen P2 LTPK.
Samsudin. Kurikulum Pendidikan Jasmani Olahraga dan Kesehatan 2013. Jakarta: POR UNJ, 2013.

Sarifudin, A. 1981. Pedoman Pelaksanaan KO-Kurikuler. Universitas Negeri Malang.

Sarumpaet, A, (1992). Permainan Besar. Semarang. Depdikbud.

Scheunemann, T. (2008). Dasar Sepakbola Modern, $2^{\text {th }} \mathrm{Ed}$. Malang. Dioma Publishing.

Scheunemann, T., Reyna, C., Perez, J., \& Gunadi, P. (2012). Kurikulum \& Pedoman Dasar Sepakbola Modern Untuk Usia Dini (U5-U12), Usia Muda (U13-U20) \& Senior. Jakarta : PSSI.

Soedjono. 1992. Konsep Pembinaan Sepakbola Usia Dini. Makalah. Yogyakarta: FPOK IKIP Yogyakarta.

Sugiyanto, dkk. Perkembangan Dan Belajar Motorik, Jakarta: Mendikbud, 2007.

Sukadiyanto., \& Muluk, D. (2011). Pengantar Teori Dan Metodologi Melatih Fisik. Bandung : CV Lubuk Agung.

Sukatamsi, Permainan Besar I Sepakbola. Jakarta: Depdikbud, 1997.

Sumantri, Mulyani dan Nana Syaodih. Perkembangan Peserta Didik. Jakarta: Universitas Terbuka Departemen Pendidikan Nasional, 2007.

Trisno. 2013. Materi Penjaskesor, (Online), (http://trisnoorsolo.blogspot.com/2013 lo1/materipenjaskesor 21.html?m=1), diakses tanggal 18 Februari 2014.

Winarno, M. E. (2006). Metode Tes Keterampilan Olahraga. Malang: Laboratorium Jurusan IImu Keolahragaan Fakultas IImu Pendidikan Universitas Negeri Malang 
Diki Satria Perdana, Pengaruh Latihan Small Sided Games 4x4 Dan 8x8 Terhadap Peningkatan Keterampilan Passing Pada Pemain Sepakbola Ekstrakurikuler Smp Negeri 2 Grati Kabupaten Pasuruan

Witarsa, Aang. Taktik Sepakbola. Jakarta:

PSSI, 1984. 